\title{
Amelogenesis Imperfecta, Hypoplastic Type Associated with Some Dental Abnormalities: A Case Report
}

\author{
Emin Murat CANGER ${ }^{1}$ \\ Peruze ÇELENK ${ }^{1}$ \\ Murat YENÍSEY ${ }^{2}$ \\ Selcen Zeynep ODYAKMAZ ${ }^{3}$
}

\author{
${ }^{1}$ Ondokuz Mayis University, Faculty of Dentistry, Department of Oral Diagnosis and Radiology, Samsun, Turkey \\ ${ }^{2}$ Ondokuz Mayis University, Faculty of Dentistry, Department of Prosthodontics, Samsun, Turkey \\ ${ }^{3}$ Ondokuz Mayis University, Faculty of Dentistry, Department of Periodontology, Samsun, Turkey
}

\begin{abstract}
Amelogenesis imperfecta (AI) is a hereditary disorder expressing a group of conditions that cause developmental alterations in the structure of enamel. AI is a serious problem that reduces oral health-related quality of life and causes some physiological problems. The treatment of patients with AI may upgrade the quality of life and reinforce their self-esteem. Among the treatment options for AI, full-mouth metal reinforced porcelain restoration constitutes an important alternative because of its properties. This paper presents a case of AI of the hypoplastic rough type associated with a group of dental anomalies, and describes the prosthetic management of the patient. A 26-year-old female patient presented with a chief complaint of discolored teeth. Clinical and radiographic examination of the patient confirmed the diagnosis of rough pattern hypoplastic AI. The patient was treated with full-mouth metal reinforced porcelain fixed bridge. The adaptation of the temporomandibular joints and masticatory muscles was carefully observed periodically during 4 months and, after this period, the patient tolerated well her new vertical dimension. The patient received instructions on cleansing of the subpontic and interproximal areas. Follow-up visits were scheduled at 3 months and then at 6 months. No esthetic or functional problems were seen after the follow up period.
\end{abstract}

Key Words: Amelogenesis imperfecta, hypoplastic type, dental anomalies, porcelain restorations.

\section{INTRODUCTION}

Amelogenesis imperfecta (AI) is a hereditary disorder that expresses a group of conditions that cause developmental alterations in the structure of enamel. The estimated frequency of $\mathrm{AI}$ in the population varies between 1:718 and 1:14.000 in western population. Generally both the primary and permanent dentitions are diffusely involved. In the affected teeth, the dentin and root form are usually normal. These teeth are more resistant to decaying (1-3). No racial predilections of the AI have been reported (1-4).

Classifications of AI are primarily based on phenotype and mode of inheritance. The most commonly used classification was proposed in 1988 by Witkop, and revised by Nusier in 2004. Based on enamel appearance and hypothesized developmental defects, AI is classified as 4 patterns: hypoplastic, hypomaturation, hypocalcified, and hypomaturation-hypoplastic (1-4).

The primary clinical problems of AI are tooth sensitivity, loss of occlusal vertical dimension, dysfunction, and esthetics. Restoration of these defects is important not only because of esthetic and functional concerns, but also because there may be a positive psychological impact for the patient. Treatment planning for patients with amelogenesis imperfecta is related to many factors: the age and socioeconomic status of the patient, the type and severity of the disorder, and the intraoral situation. An interdisciplinary approach is necessary to evaluate, diagnose, and resolve esthetic problems

Correspondence: Dr. Emin Murat Canger, Ondokuz Mayis University, Faculty of Dentistry, Department of Oral Diagnosis and Radiology, Samsun, Turkey. Tel: +90-362-3121919/3012. Fax:+90-362-4576032. e-mail: emcanger@omu.edu.tr 
using a combination of periodontal, prosthodontic, and restorative treatment $(1,4)$.

The aim of this paper is to outline the management of esthetics and function with prosthetic approach in a patient with amelogenesis imperfecta of the hypoplastic type accompanied with tooth impaction and some other dental anomalies.

\section{CASE REPORT}

A 26-year-old female patient presented with a chief complaint of discolored teeth. Medical history was noncontributory. Extraoral examination did not reveal any relevant findings. No other family member had the same dental problem.

The patient's oral hygiene was poor and she presented hyperemic and edematous gingiva. Bleeding on probing scores of the teeth was determined as one. There was no gingival enlargement around the teeth, so the clinical crown lengths were adequate. Twenty-three teeth were erupted. Six of them were primary teeth (55, $52,75,73,83$ and 85$)$ and 17 were permanent teeth (16, $14,13,11,21,22,24,25,26,36,34,32,31,41,42,44$, 46). Tooth crowns were clinically short and featured yellow-brown colored surfaces. Tissue loss affected all teeth. There was loss of contact between the teeth. Vertical dimension of the face was also decreased. There was no anterior open bite (Fig. 1).

Panoramic and full-mouth periapical radiograms of the patient were obtained. Radiographic examination revealed that 15 of the permanent teeth were totally impacted $(18,17,15,23,27,28,38,37,35,33,43,44$, $45,47,48)$. Over-retention was observed in 6 primary teeth $(55,52,75,73,83,85)$. Permanent maxillary right lateral incisor was also congenitally missing (Fig. 2a).

Additionally, pulpal calcifications were found on 23 teeth $(17,16,15,55,14,13,23,25,26,27,38,37$, $36,35,75,33,34,43,44,45,46,47,48)$. Also external resorption was noted on the crowns of all 4 impacted permanent 2nd molars.

Radiographically, the enamel layers of all teeth

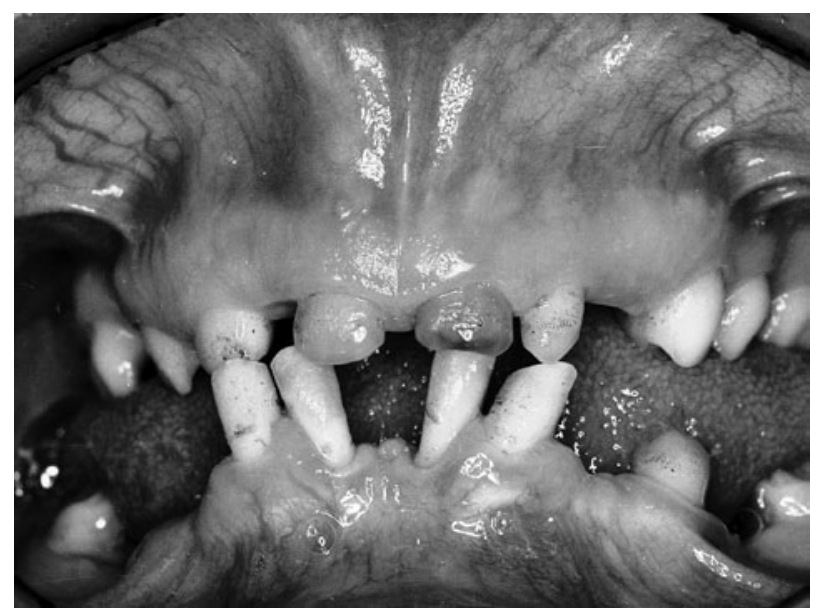

Figure 1. View of the maxillary and mandibular teeth in occlusion revealing neither anterior open bite nor gingival enlargement around the teeth present in the oral cavity. Tooth crowns are clearly seen as clinically short and featured with yellow-brown colored surfaces.
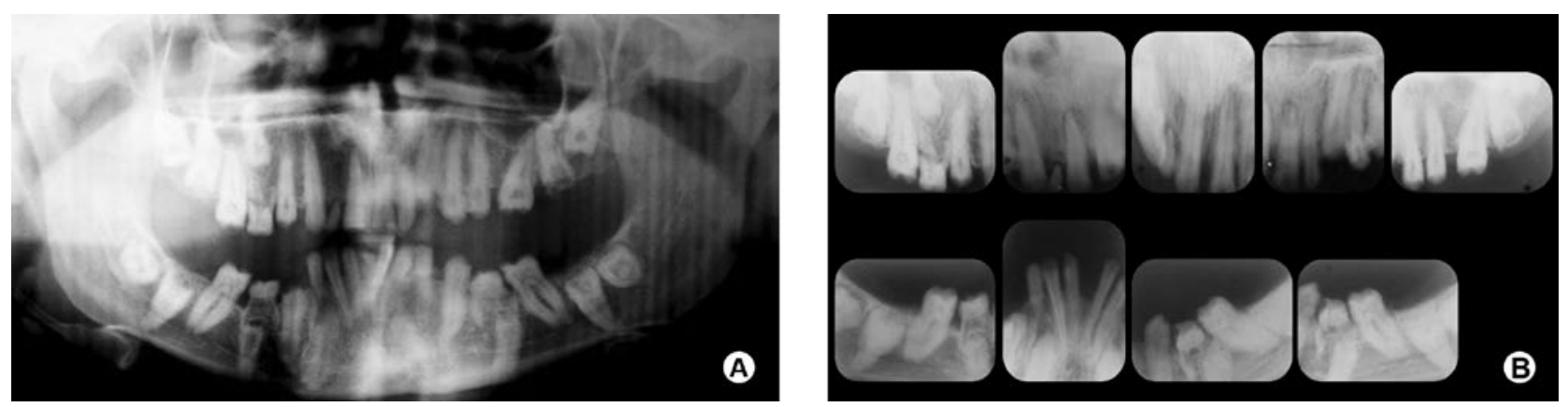

Figure 2. Radiographic appearance. A = Panoramic radiograph of the patient revealing the presence of 6 over-retained primary teeth $(55,52,75,73,83,85)$ and 15 totally impacted permanent teeth $(18,17,15,23,27,28,38,37,35,33,43,44,45,47,48)$. Pulpal calcifications are seen in all teeth and congenital absence of maxillary right lateral tooth is clearly visible. $\mathrm{B}=$ Full-mouth periapical radiographs of the maxilla and mandible. The density of dentin is not differentiated from enamel. The loss of contact between the teeth can be easily detected. External coronal malformation was performed on both impacted 2nd permanent molars. 
were absent, giving an appearance similar to that observe after mechanical preparation.

Pulp chambers had normal size and shape except for the maxillary left-right 1 st molars. There were stones in the crown pulps and the radicular pulps were obliterated. In addition, external resorption was noted on the crowns of both impacted 2nd permanent molars.

The lamina duras were normal. The crowns of mandibular left central incisors and lateral incisors became close to each other and the roots were separated from each other (Fig. 2b).

The 6 over-retained primary teeth $(55,52,75,73$, $83,85)$ were extracted. Since the impacted permanent teeth had not caused problems like dentigerous cysts, they were preserved and observed periodically at 1 -year intervals. Case progression is under continuous evaluation and no problems have appeared so far.

The initial stage periodontal therapy consisted

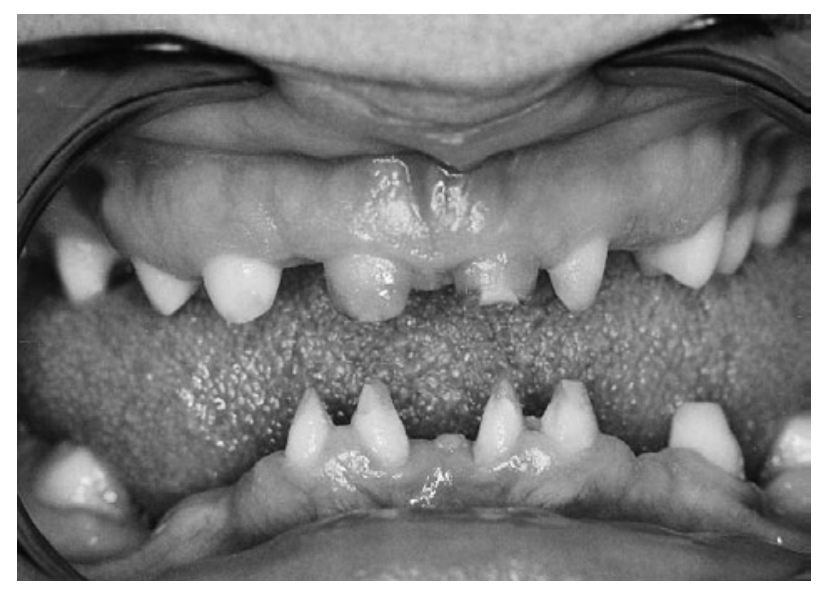

Figure 3. Preparations of the maxillary and mandibular teeth. of oral hygiene instructions, scaling, and root planning. Two weeks later, the gingival edema was resolved and hyperemic appearance of gingiva turned to normal. Also bleeding on probing was normal.

After radiographic examination of crown/root ratio, root number and morphology of the present teeth, construction of full-mouth metal reinforced porcelain fixed bridge restoration was planned. The occlusal vertical dimension was $3 \mathrm{~mm}$ lower than normal. First of all, a splint, made of self cured hard acrylic, was constructed to increase the vertical dimension. The adaptation of the temporomandibular joints and masticatory muscles was carefully observed periodically during 4 months and, after this period, the patient tolerated well her new vertical dimension.

The supporting teeth were prepared $1 \mathrm{~mm}$ axially, occlusally and incisally to provide sufficient space for denture (Fig. 3a). Impressions were obtained by putty and light viscosity of addition silicon material (Elite putty \& Light; Zhermack, Rovigo, Italy). After metal framework and porcelain trail stage, and the glasure stage, fixed partial dentures were cemented with polycarboxilate cement (Adhesor Carbofine; Spofa Dental, Hungary) (Fig. 4).

The patient received instructions on cleansing of the subpontic and interproximal areas, and was reexamined after 1 week. Follow-up visits were scheduled at 3 months and then at 6 months. No esthetic or functional problems were seen after the follow up period.

\section{DISCUSSSION}

Clinical presentation of the AI varies according to its type. In the hypomaturation type, the affected teeth exhibit mottled, opaque white-brown yellow discolored
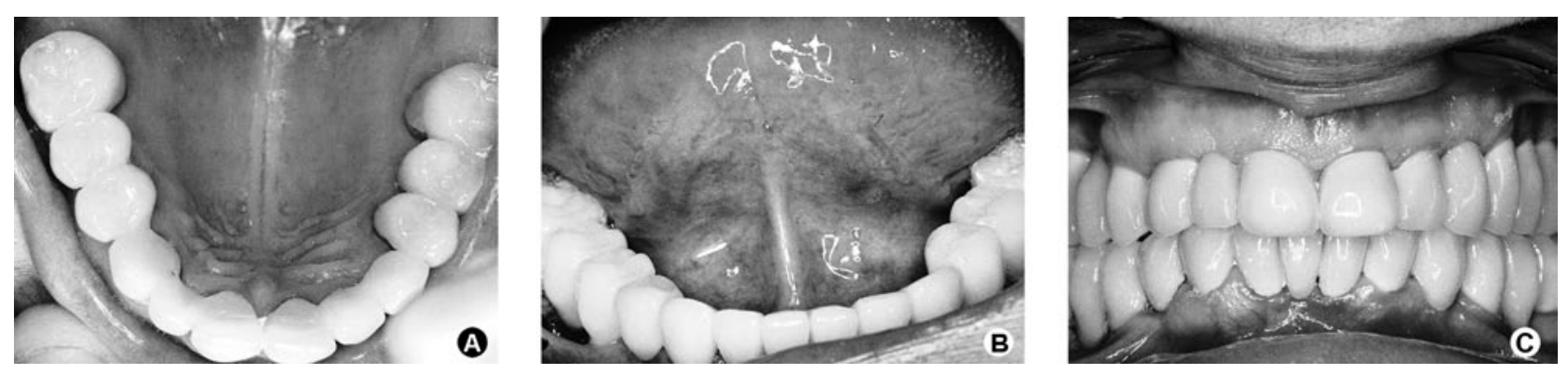

Figure 4. Intraoral clinical appearance after the completion of the restorative treatment. A = View of completed maxillary restorations. $\mathrm{B}=$ View of completed mandibular restorations. $\mathrm{C}=$ Post-treatment view of the teeth in maximum intercuspation. 
enamel, which is softer than normal. In radiographs, the thickness of enamel is normal, but its density is the same as that of the dentin. The hypocalcified type shows pigmented, softened, and easily detachable enamel. Radiographically, enamel thickness is normal, but its density is even less than that of the dentin. In the hypoplastic type, the enamel is well-mineralized but its amount is reduced. Clinically grooves and pits will be realized on the surface of the fine enamel. The rough pattern of hypoplastic type, exhibits thin, hard, and rough surfaced enamel. The tooth is tapered towards the incisal/ occlusal face and has open contact points. Radiographs exhibit a thin peripheral outline of radiodense enamel, and low or absent cusps $(1,2)$. Clinical and radiographic appearances of the teeth of our case were harmonious with rough pattern hypoplastic type AI.

AI may be associated with some other dental and skeletal developmental defects or abnormalities, such as crown and root resorption, attrition, taurodontism, delayed eruption and tooth impaction, dens in dente, pulp stones, anterior open bite and agenesis of teeth. In our case, tooth impaction, delayed eruption, crown resorption, pulp stones, and tooth agenesis were present. Up to date, 15 cases of delayed eruption, 14 cases of pulp stones, 9 cases of tooth agenesis have been reported (5). According to Seow (6), pulp stones are formed as the result of the external local irritation because of the thin enamel layer and attrition. However, the findings of the present case do not agree with this suggestion, since the 5 unerupted temporary teeth revealed pulpal calcifications which are not under the thread of such irritations. Again, although the exact reasons of pathosis of tooth eruption are unclear, Seow (6) suggested that this situation was associated the resorption of the enamel and tooth ankylosis. The exposure of the dentin caused by the removal of abnormal enamel leads to tooth resorption and consequent ankylosis. Also, it has been reported that the most severe cases of impaction occurs in autosomal recessive hypoplastic type AI. This situation appeared to involve an abnormality in the molecular control of the eruption process (5).

The gingiva of our patient was hyperemic and edematous. Until now, 40 papers have been published reporting the gingival conditions of patients with $\mathrm{AI}$, and 28 of them had edematous and hyperemic gingival (5). This condition contributed to the mouth breathing and reluctance to brush because of the sensitive teeth $(8,9)$. Along with poor oral hygiene, the factors adversely affect the prognosis of the prosthetic treatment $(4,8)$. The oral health of our patient was maintained after conventional periodontal therapy.

Eight teeth of the patient of this case failed to erupt. Seow (6) showed that people with AI have 6 times the tendency of unaffected people to have impaction of permanent teeth.

Few clinical reports have been presented describing the restorations of individuals affected by amelogenesis imperfecta (7-15). Currently, the cases of AI are restored with adhesive restorative techniques, overdentures, fixed partial dentures, full porcelain crowns, porcelain fused-to metal crowns and inlay/onlay restorations constitute the contemporary treatment modalities. Overdentures have been suggested for children, because they are alterable to accommodate an active growth process. However, adequate interocclusal space must exist. Meanwhile, full porcelain restorations are becoming increasingly popular, because of their inheriting esthetics, excellent biocompatibility and improved physical properties.

Several authors (7-12) prefer full porcelain restorations as the treatment modality of their patient with AI. However, the advances in the field of esthetic dentistry, especially in bonding to dentin, help practitioners to restore function and esthetics to an acceptable level $(7,13,14)$. Nevertheless, marginal adaptation and bonding problems have been pointed out as disadvantages of laminate veneers (12), Sari and Usumez (15) combined these two treatment modalities by applying porcelain laminate veneers for anterior teeth and full porcelain dentures for maxillary and mandibular posterior teeth in their case. In the present case, full-mouth metal-reinforced porcelain restorations were preferred to redouble the mechanical durability, recover esthetics and protect the residual dentin. Since there was no enough tooth structure in the anterior region, laminate veneer restoration was not used.

In conclusion, $\mathrm{AI}$ is a serious problem that can result in reduced oral health-related quality of life and causes some physiological problems. From this point of view, people with AI need extensive treatment. While planning the treatment, the age and the socioeconomic status of the patient, type and the severity of the disorder should be taken into consideration. Moreover, although rare, some dental anomalies may accompany the AI cases. In these cases, multidisciplinary approach is important for treatment success. In the present case, 
the patient tolerated well the use of dentures after the routine controls.

\section{RESUMO}

Amelogenesis imperfecta (AI) é uma desordem hereditária que expressa um grupo de condições que causam alterações de desenvolvimento na estrutura do esmalte. A AI é um problema grave que compromete a qualidade de vida relacionada à saúde bucal e causa alguns problemas psicológicos. $\mathrm{O}$ tratamento de pacientes com AI pode melhorar sua qualidade de vida e reforçar sua autoestima. Dentre as opções de tratamento para AI, a restauração de toda a boca com porcelana reforçada com metal representa uma alternativa importante devido a suas propriedades. Este artigo apresenta um caso de AI do tipo hipoplásica rugosa associada a um grupo de anomalias dentais, e descreve o tratamento protético da paciente. Uma paciente de 26 anos apresentou-se com queixa principal de dentes manchados. O exame clínico e radiográfico da paciente confirmou o diagnóstico de AI hipoplásica rugosa. A paciente foi tratada com a construção de próteses fixas de porcelana reforçada com metal em toda a boca. A adaptação das articulações temporomandibulares e dos músculos mastigatórios foi cuidadosamente observada periodicamente durante 4 meses e, após este período, a paciente mostrou tolerar bem sua nova dimensão vertical. A paciente recebeu instruções sobre limpeza das áreas sob o pôntico e áreas interproximais. As visitas de acompanhamento foram agendadas a cada 3 meses e subseqüentemente a cada 6 meses. Não foram observados problemas estéticos ou funcionais após o período de acompanhamento.

\section{REFERENCES}

1. Neville BW, Douglass DD, Allen CM, Bouquot JE. Abnormalities of teeth. In: Oral and Maxillofacial Pathology. $2^{\text {nd }}$ ed.. Pennsylvania:Elsevier;2004. 89-94.

2. Bailleul-Forestier I, Molla M, Verloes A, Berdal A. The genetic basis of inherited anomalies of the teeth. Part 1: clinical and molecular aspects of non-syndromic dental disorders. Eur J Med Genet 2008;51:273-291.
3. Santos MCLG, Line SRP. The genetics of amelogenesis imperfecta: a review of the literature. J Appl Oral Sci 2005;13:212-217.

4. Crawford PJM, Aldred M, Bloch-Zupan A. Amelogenesis imperfecta. Orphanet J Rare Dis 2007;2:17-27.

5. Poulsen S, Gjqrup H, Haubek D, Haukali G, Hintze H, Lqvschall $\mathrm{H}$, et al.. Amelogenesis imperfecta - a systematic literature review of associated dental and oro-facial abnormalities and their impact on patients. Acta Odontol Scand 2008;66:193-199.

6. Seow WK. Dental development in amelogenesis imperfecta: a controlled study. Pediatr Dent 1995; 17:26-30.

7. Gökçe K, Canpolat C, Özel E. Restoring function and esthetics in a patient with amelogenesis imperfecta: a case report. J Contemp Dent Pract 2007;8:90-101.

8. Siadat H, Alikashi M, Mirfazaelian A. Rehabilitation of a patient with amelogenesis imperfect using all-ceramic crowns: a clinical report. J Prosthet Dent 2007;98:85-88.

9. Toksavul S, Ulusoy M, Türkün M, Kümbüloğlu Ö. Amelogenesis imperfecta: the multidisciplinary approach: a case report. Quintessence Int 2004;35:11-14.

10. Sadighpour L, Geraminapah F, Nikzad S. Fixed rehabilitation of an ACP PDI class III patient with amelogenesis imperfecta. J Prosthodont 2009;18:64-70.

11. Kostoulas I, Kourtis S, Andritsakis D, Doukoudakis A. Functional and esthetic rehabilitation in amelogenesis imperfecta: a case report. Quintessence Int 2005;36:329-338.

12. Ozturk N, Sari Z, Ozturk B. An interdisciplinary approach for restoring function and esthetics in a patient with amelogenesis imperfecta and malocclusion: a clinical report. J Prosthet Dent 2004:92:112-115.

13. Christensen GJ. Porcelain-fused-to-metal versus nonmetal crowns J Am Dent Assoc 1999;130:409-411.

14. Şengün A, Özer F. Restorating function and aestehetics in a patient with amelogenesis imperfect: a case report. Quintessence Int 2002;33:199-204.

15. Sari T, Usumez A. Restoring function and esthetics in a patient with amelogenesis imperfecta: a clinical report. J Prosthet Dent 2003;90:522-525. 